\title{
ВПРОВАДЖЕННЯ КЕЙС-МЕТОДУ ПРИ ВИКЛАДАННІ ТЕМИ “КОМИ ПРИ ЦУКРОВОМУ ДІАБЕТІ” ЛІКАРЯМ-ІНТЕРНАМ ЗІ СПЕЦІАЛЬНОСТІ “АНЕСТЕЗІОЛОГІЯ”
}

\author{
O. Ye. Sichkoris, O. V. Ivaniushko, I. A. Pavlenko \\ Danylo Halytskyi Lviv National Medical University \\ INTRODUCTION OF THE CASE-STUDY IN TEACHING THE THEME \\ OF COMATOSE CONDITIONS IN DIABETIC PATIENTS FOR INTERNS \\ ON SPECIALTY OF ANESTHESIOLOGY
}

\begin{abstract}
Мета роботи - визначити ефективність впровадження кейс-методу при викладанні теми “Коми при цукровому діабеті”, його дієвість щодо засвоєння конкретних питань.

Основна частина. Розглядається ситуація виникнення коми у пацієнта з цукровим діабетом, казус, який стався при різних життєвих обставинах. Виокремлюється низка практичних завдань, що витікають із логіки невідкладної медичної допомоги та інтенсивної терапії коми при цукровому діабеті. Інтернам необхідно проаналізувати ситуацію, розібратися у суті проблеми та запропонувати можливі варіанти рішень - визначити вид коми та вибрати протокол надання допомоги.

Висновки. Впровадження кейс-методу дає можливість лікарям-інтернам застосувати теоретичні знання з різних дисциплін для вирішення практичних завдань з діагностики та лікування цієї патології. Його також доцільно застосовувати при організації навчання лікарів-інтернів суміжних спеціальностей із подальшим обговоренням особливостей конкретної клінічної ситуації. За допомогою цього методу майбутні спеціалісти мають можливість проявити та вдосконалити аналітичні навички з надання невідкладної медичної допомоги при цукровому діабеті, знаходити найраціональніше вирішення поставленої задачі, навчитися командно працювати. Викладач стає творцем умов, за яких лікарі-інтерни мають змогу змістовніше оволодіти фаховими знаннями $з$ діагностики та надання медичної допомоги при загрозливих ускладненнях цукрового діабету - комах, що визначає їх професійну компетентність. Застосована інноваційна технологія $€$ перспективним напрямком і завдяки інтерактивності покращить якість освітнього процесу на післядипломному етапі навчання.
\end{abstract}

Ключові слова: медична освіта; кейс-метод; цукровий діабет; кома.

The aim of the work - to determine the effectiveness of the case-method implementation in teaching the theme of Comatose conditions in diabetic patients, its effectiveness in assimilating the specific issues.

The main body. The introduction of the case-study method enables the interns to apply theoretical knowledge from different disciplines in order to solve practical problems in the diagnosis and treatment of this pathology. It is also advisable to use it in organizing the training of interns of the adjacent specialties with the further discussion of the peculiarities of a particular clinical situation. Due to this method, future specialists have the opportunity to demonstrate and improve their analytical skills in providing urgent medical care in diabetes mellitus to find out the most appropriate solution of the purpose-oriented task, and to be capable enough to work as a medical team.

Conclusions. The teacher initiates the conditions in which interns have the opportunity to gain more proficient knowledge in diagnosis and to rendes medical care in case of life-threatening complications comatose conditions in diabetic patients, which determines their professional competence. The applied innovative technique is a promising direction and due to its interactivity will improve the quality of the educational process during the postgraduate level of studies.

Key words: medical education; case-method; diabetes mellitus; coma.

Вступ. Актуальність впровадження кейс-методу в практику вищої медичної освіти на післядипломному етапі навчання визначається формуванням професійних умінь лікарів-інтернів, зміни у них парадигми мислення, здатності оптимально реагувати в екстрених клінічних ситуаціях [2, 7]. Метод,

(C) О. Є. Січкоріз, О. В. Іванюшко, І. А. Павленко в основі якого лежить ідея проблемного мислення, вперше реалізована викладачем Гарвардської юридичної школи К. Ленгделлом і базується на концепції розвитку розумових здібностей, у використанні конкретних випадків, зокрема історій, тексти яких називають “кейсом”, для спільного аналітичного розбору, обговорення та прийняття рі- 
шень. Цінність кейс-методу полягає в одночасному відображенні практичної проблеми з актуалізацією певного комплексу знань, що поєднує навчальні, аналітичні та виховні аспекти $[1,8]$.

Медичні кейси відрізняються від інших (економічних, педагогічних, юридичних) тим, що містять, крім загальної, ще й детальну інформацію, зокрема: історію захворювання, опис клінічної картини, результати обстеження, протоколи лікування тощо. Це інтерактивний спосіб аналізу конкретної ситуації, яка висвітлює стан здоров’я пацієнта, проведення диференційної діагностики та вибору лікувальної тактики $[3,6]$. Він скерований більше на формування професійної компетентності, вмінь та навичок розумової діяльності, аніж отримання нових знань, та включає набір клінічних випадків у процесі навчання з подальшим аналізом в інтерактивному режимі. Важливою складовою кейс-методу є оцінка дій майбутнього спеціаліста та розбір допущених помилок [8].

Незважаючи на покращення організації діабетологічної допомоги в Україні, коми при цукровому діабеті (ЦД) посідають друге місце серед всіх видів коматозних станів (КС). Це надзвичайно тяжке ускладнення, яке вимагає невідкладної медичної допомоги (НМД) на ранньому етапі лікування. І власне від умінь і навичок лікаря вчасно діагностувати цей вид коми та надати кваліфіковану медичну допомогу залежить прогноз життя пацієнта [4].

Мета роботи - визначити ефективність впровадження кейс-методу при викладанні теми “Коми при цукровому діабеті”, його дієвість щодо засвоєння конкретних питань, прикладного застосування вироблених умінь та навичок при лікуванні коми, а також володіння прийомами всебічного аналізу ситуації.

Основна частина. Під час заняття перед лікарями-інтернами ставлять конкретні цілі, такі, як: визначення порушення свідомості за шкалою ком Глазго, верифікації коми у пацієнта з ЦД, диференціація клінічних проявів КС при ЦД, надання НМД, особливості догляду за пацієнтом, призначення інтенсивної терапії (IT) згідно з протоколами MO3 України, вибір лікарських засобів, клінікофармакологічні властивості, спосіб застосування та побічна дія.

Основою методу є ситуація виникнення коми у пацієнта з ЦД, казус, який стався при різних життєвих обставинах. Лікарі-інтерни повинні проаналізувати ситуацію, розібратися у суті проблеми й запропонувати можливі варіанти рішень - визначити вид коми та вибрати протокол надання допомоги.
Особливість технології полягає в тому, що викладач використовує вже напрацьовану чи розроблену власну модель конкретної ситуації коми при ЦД, підбирає навчальну інформацію, визначає проблеми, ставить питання, на які лікарі-інтерни мають знайти відповідь, при цьому користуючись основним та додатковим навчальним матеріалом. Джерело кейсу - проблемна ситуація (хворий без свідомості), відповідний стан реальності (знайдений на вулиці, вдома, доставлений бригадою ШМД), у який потрапляють діючі особи (лікар, медсестра, родичі, сусіди, перехожі) [5, 9].

Основні вимоги до ситуації: актуальність, важливість, доречність, реалістичність, мати протиріччя, яке є основою для виокремлення проблеми. Лікарям-інтернам необхідно провести диференційну діагностику коми, окреслити поступовість дій у конкретній клінічній ситуації. Орієнтиром для викладача під час формування чітких питань $€$ визначення проблематики і реперних точок життєво важливих функцій організму: рівня свідомості, артеріального тиску, пульсу, частоти, типу дихання, рівня глікемії, вибір лікарського засобу, його дози та шляху введення. Необхідно урізноманітнювати стиль, розмір, форму та змінювати формат ситуацій, текст опису якої має бути цікавим і зрозумілим для слухачів [8]. Опрацювання кейсу на занятті відбувається у підгрупах, обговорюються проблеми КС при ЦД та шляхи ії розв’язання (укладка пацієнта, забезпечення прохідності верхніх дихальних шляхів, експрес-діагностика, введення медикаментів). Далі йде навчальна дискусія: з різних позицій аналізується конкретна ситуація виникнення коми, іiї діагностика, можливі причини, помилки при веденні пацієнта з ЦД, пропонуються дії з надання НМД протоколів та їх застосування в певних обставинах, оцінюється ефективність лікування, прогнозується перебіг захворювання. Викладач координує процес: ставить питання, фіксує відповіді, підтримує обговорення, але уникає прямих порад; аналізує та визначає кращі результати, оцінює роботу кожної підгрупи і кожного лікаря-інтерна зокрема. В процесі обговорення теми активізується розумова діяльність інтернів через актуалізацію мультидисциплінарних знань, розвиваються їх практичні вміння визначення глибини коми, диференціації КС пацієнта, роботи з отриманою інформацією, напрацювання навиків прийняття професійних рішень з надання НМД при комах, госпіталізації пацієнта та вміння комунікацій [6]. Відбувається взаємозв’язок між інтернами та викладачем, тому 
кейс-метод виокремлюється як одна із форм інтерактивного навчання [1, 3].

Вирішується методична мета ілюстрацією до теорії і суто практичною ситуацією (чи їх поєднанням), аби зацікавити лікарів-інтернів. Цьому сприяє напруженість та екстреність описаної події, що вимагає прийняття швидких рішень [5]. Текст кейсу повинен містити вступ по суті проблеми коми при ЦД, випадку захворювання, клінічний протокол, результати ефективності лікування тощо. У змісті кейсу відображаються навчальні цілі та дозована інформація для швидкої орієнтації в темі, зручно, коли вона подається у форматі таблиць, графіків, відеороликів, мультимедійних презентацій. Проте це не має бути простим описом ситуації чи сухими даними, факти повинні комбінуватися таким чином, щоб лікарі-інтерни уявно потрапляли у реальну клінічну ситуацію, могли дискутувати, концентруючи увагу на отриманих результатах, а не лише на демонстрації їх цінності $[3,5,6]$.

Робота викладача над кейсом вимагає ерудиції, часу та педагогічної майстерності. Для успішного впровадження методу case-study у викладанні теми “Коми при цукровому діабеті” йому необхідно: переосмислити навчальний матеріал з позиції виокремлення та моделювання проблемних ситуацій за даною тематикою в практиці лікаря; напрацювати способи їх подання (усні, письмові, наочні, мультимедійні тощо); чітко виділяти проблему, оскільки вона знаходиться не в кожній навчальній інформації. При відборі проблемних ситуацій необхідно враховувати важливість рішень лікарів, необхідність застосування клінічних протоколів надання допомоги, значущість рятування життя. Доаудиторна робота - це підготовка в достатній кількості питань та ситуаційних задач по темі заняття, роздаткових матеріалів (історії хвороб, протоколи лікування, лабораторні дані) і матеріальнотехнічного забезпечення (тонометри, глюкометри, інсулінові шприци, системи для внутрішньовенних інфузій, лікарські засоби, ноші). В аудиторії діяльність викладача розпочинається зі вступної бесіди про актуальність, поширеність ускладнень ЦД у загальній популяції населення, важливість надання допомоги при комі, він організовує роботу підгруп для вивчення кейсу і прийняття рішення, координує дискусію, підтримує належний рівень зацікавленості та активних комунікацій у групах, оцінює внесок кожного лікаря-інтерна в аналіз ситуації та пошук шляхів її розв’язання. На завершення викладач проводить контроль самостійної позааудиторної пізнавальної роботи за темою кейсу та підводить підсумки. До критеріїв оцінювання лікаряінтерна належать: активність в обговоренні кейсу 3 урахуванням міждисциплінарної інтеграції, участь у роботі групи та самостійна робота з підготовки до заняття [8]. Кейс-метод доцільно застосовувати також при проходженні навчання на кафедрі анестезіології та інтенсивної терапії лікарів-інтернів суміжних спеціальностей (медицина невідкладних станів, сімейна медицина тощо), у випадку, коли у відділенні IT на той момент немає пацієнтів в КС.

За нашими спостереженнями, встановлено, що кейс-метод стимулює індивідуальну активність лікарів-інтернів при вивченні теми “Коми при цукровому діабеті”, формує позитивну мотивацію до навчання та зменшує кількість “пасивних” і невпевнених у собі осіб, а також надихає викладача оновлювати власний творчий потенціал. Все це забезпечує високу ефективність вивчення невідкладних станів при ЦД і формує необхідні особистісні якості і професійні компетентності лікарів-інтернів.

Висновки. Впровадження кейс-методу при викладанні теми “Коми при цукровому діабеті” дає можливість лікарям-інтернам застосувати теоретичні знання з різних дисциплін для вирішення практичних завдань 3 діагностики та лікування цієї патології. Він сприяє розвитку самостійного мислення, вміння вислухати та врахувати альтернативну точку зору, аргументовано висловити свою думку, швидко приймати професійні рішення. За допомогою цього методу майбутні спеціалісти мають можливість проявити та вдосконалити аналітичні навички з надання НМД при ЦД, знаходити найраціональніше вирішення поставленої задачі, навчитися командно працювати. Викладач створює умови, які визначають професійну компетентність лікарів-інтернів, оскільки вони мають змогу змістовніше оволодіти фаховими знаннями 3 діагностики та надання допомоги при загрозливих ускладненнях ЦД. Застосована інноваційна технологія $є$ перспективним напрямком, завдяки інтерактивності покращить якість освітнього процесу на післядипломному етапі навчання. Проаналізована ефективність кейс-методу вказує на доцільність його впровадження при викладанні теми “Коми при цукровому діабеті”. 


\section{Список літератури}

1. Андрущак Т. Г. Особливості організації процесу фахової підготовки на основі кейс-методу / Т. Г. Андрущак. Черкаси, 2015. - С. 218-222.

2. Зіменковський Б. С. Рейтинг як складова системи управління якістю підготовки лікарів і провізорів / Б. С. Зіменковський, М. Р. Гжегоцький, І. І. Солонинко // Медична освіта. - 2012. - № 2. - С. 49-51.

3. Максименко С. Д. Педагогіка вищої медичної освіти / С. Д. Максименко, М. М. Філоненко. - К. : Центр учбової літератури, 2014. - С. 109-116.

4. Медицина невідкладних станів: Швидка і невідкладна медична допомога / ред. І. С. Зозуля. - К. : ВСВ “Медицина”, 2012. - С. 437-468.

5. Павленко I. А. Кейс-метод у викладанні теми “Коматозні стани” / І. А. Павленко // Медицина неотложных состояний. - 2016. - № 8. - С. 119-123.

\section{References}

1. Andrushchak, T.H. (2015). Osoblyvosti orhanizatsii protsesu fakhovoi pidhotovky na osnovi keis-metodu [Features of the organization of the process of professional training on the basis of the case-method]. Cherkasy [in Ukrainian].

2. Zimenkovskyi, B.S., Hzhehotskyi, M.R., \& Solonynko, I.I. (2012). Reitynh yak skladova systemy upravlinnia yakistiu pidhotovky likariv i provizoriv [Rating as a component of the quality management system for the training of doctors and pharmacists]. Medychna Osvita Medical Education, 2, 49-51 [in Ukrainian].

3. Maksymenko, S.D., \& Filonenko, M.M. (2014). Pedahohika vyshchoi medychnoi osvity [Pedagogics of higher medical education]. Kyiv: Tsentr uchbovoi literatury, 109-116 [in Ukrainian].

4. Zozulia, I.S. (Ed.) (2012). Medytsyna nevidkladnykh staniv: Shvydka i nevidkladna medychna dopomoha [Emergency medicine: Emergency and emergency medical care]. Kyiv: Medytsyna [in Ukrainian].

5. Pavlenko, I.A. (2016). Keis-metod u vykladanni temy "Komatozni stany" [Case method in the teaching of the

Електронна адреса для листування: irunapavlenko@gmail.com
6. Путинцев А. Н. Кейс-метод в медицинском образовании: современные программные продукты / А. Н. Путинцев, Т. В. Алексеев // Международный журнал прикладных и фундаментальных исследований. - 2016. № 12-9. - С. 1655-1659.

7. Рашкевич Ю. М. Болонський процес та нова парадигма вищої освіти / Ю. М. Рашкевич. - Львів : Видавництво Львівської політехніки, 2014. - 168 с.

8. Філоненко М. М. Методика викладання у вищій медичній школі на засадах компетентнісного підходу / М. М. Філоненко. - К. : Центр учбової літератури, 2016. - 88 c.

9. Aronson L. Twelve tips for teaching reflection at all level of medical education / L. Aronson // Med. Teacher. - 2011. Vol. 33 (3). - P. 200-205.

theme "Comatic states"]. Meditsina neotlozhnykh sostoyaniy - Medicine of Emergency Conditions, 8, 119-123 [in Ukrainian].

6. Putintsev, A.N., \& Alekseev, T.V. (2016). Keis-metod v meditsinskom obrazovanii: sovremennye programmnye produkty [Case method in medical education: modern software products]. Mezhdunarodnyi zhurnal prikladnykh $i$ fundamentalnykh issledovaniy - International Journal of Applied and Fundamental Research, 12-9, 1655-1659 [in Russian].

7. Rashkevych, Yu.M. (2014). Bolonskyi protses ta nova paradyhma vyshchoi osvity [Bologna process and new paradigm of higher education]. Lviv: Vydavnytstvo Lvivskoi politekhniky [in Ukrainian].

8. Filonenko, M.M. (2016). Metodyka vykladannia u vyshchii medychnii shkoli na zasadakh kompetentnisnoho pidkhodu [Methodology of teaching in the higher medical school on the basis of competence approach]. Kyiv: Tsentr uchbovoi literatury [in Ukrainian].

9. Aronson, L. (2011). Twelve tips for teaching reflection at all level of medical education. Med. Teacher, 33 (3), 200-205.

Отримано 07.05.18 